\title{
DEFINITION OF SENSITIZATION TO POLLEN ALLERGENS WORMWOOD AND HAZEL IN PATIENTS WITH RESPIRATORY ALLERGIC DISEASES BY IMMUNOBLOT AND MULTIPLEX COMPONENT TEST
}

\author{
BOGOMOLOV A.E. ${ }^{1}$, ZAYKOV S.V. ${ }^{2}$ \\ ${ }^{1}$ Vinnitsia National Medical University named after M.I. Pirogov \\ ${ }^{2}$ National Medical Academy of Postgraduate Education named after P.L. Shupika
}

Specific diagnosis of respiratory allergic diseases is an indispensable component of allergology, which must be used at the stage of diagnostic search in a patient with allergopathology [1-3].

The place of each of these methods in the patient's itinerary, however, is being actively discussed with the advent of new and new methods available for routine practice $[4,5]$.

The aim of our study was to evaluate the diagnostic parameters of immunoblot and Immunocap ISAC methods to determine allergic sensitization to wormwood and hazel in patients with respiratory allergic diseases - allergic rhinitis and bronchial asthma.

\section{Materials and methods}

In this study, 40 patients with bronchial asthma and / or allergic rhinitis were examined by two different methods of specific allergic diagnosis (in vitro). The study was open-ended, comparative. All the patients were interviewed and signed a letter of informed consent to participate in the study. All women were interviewed for possible pregnancy.

Quantitative determination of specific IgE in the serum was performed using the RIDA® AllergyScreen immunoblot method (R-Biopharm AG, Germany) at the private laboratory of "Allergo-Immunological Center KPP".

The RIDA A AllergyScreen test (panels $1,2,3,4$ ) is based on the immunoblot principle. Specific allergens, corresponding to the composition of the panel, are deposited on the surface of nitrocellulose membranes (strips). IgE antibodies specific to these allergens present in the blood samples of patients react with antigens, thereby providing at the second stage of incubation the attachment of antibodies to human IgE conjugated with antibodies (exhibiting antibodies) to strips of allergens on strips. For the testing, we used panel 2 (respiratory), which contained the following allergens: house dust (Derm. Pteronyssinus, Derm. Farinae), alder, birch, hazel, oak, herb mixture, rye, wormwood, plantain, epidermal allergens of horse, dog, guinea pig, hamster, rabbit, Alternaria alternata, Penicillium notatum, Cladospor. herbarum, Aspergillus fumigatus.

According to the existing criteria, the results were interpreted depending on the concentration of specific $\lg E$ as a class $0-6$. Class $\geq 1$ was interpreted as positive. In clinical practice, allergens with results greater than grade 2 ( $\mathrm{slgE} \geq 0.7 \mathrm{Ku} / \mathrm{I}$ ) were considered positive. After receiving the results, all data were converted to nominal scales.

ImmunoCAP Allergy Chip (Phadia AB, Thermo Fisher Scientific, Sweden) - a method for quantitative measurement of IgE-antibodies to various allergens in the serum, developed by Phadia, examination by the Immunocap ISAC method was performed at the Clinic of Allergology and Immunology. The method allows one to determine at the same time the presence of class $E$ antibodies to 112 allergen components from 51 sources of allergens - food, pollen, epidermal allergens of animals, allergens of fungi and insects, house dust mites on the immune solid-phase allergy chip (ISAC). After the results were obtained, all data were also converted to nominal scales.

Statistical processing of the results, plotting and distribution of statistical analysis values was performed using IBM SPSS Statistics 21 software package.

\section{Results}


In the main phase of the study 40 people aged 19-42 years were selected, the average age of the group was 31.6 years (95\% Cl: $26.6 ; 41.6)$, gender distribution $-60.0 \%$ of men and $40.0 \%$ of women.

Among the patients, allergic sensitization to wormwood was $27.5 \%$ (11 people) by the presence of specific IgE by the Rida AllergyScreen, $25.0 \%$ (10 people) by the presence of specific IgE by the ImmunoCAP ISAC; sensitization to hazel allergen was $27.5 \%$ (11 people) by the presence of specific IgE by the Rida AllergyScreen, $30.0 \%$ (12 people) by the presence of specific IgE by the ImmunoCAP ISAC.

Table 1 shows the results of constructing the affinity table of the results of determining specific $\lg E$ to wormwood.

Table 1

Summary table of the affinity of the results of determination of specific IgE to allergen wormwood

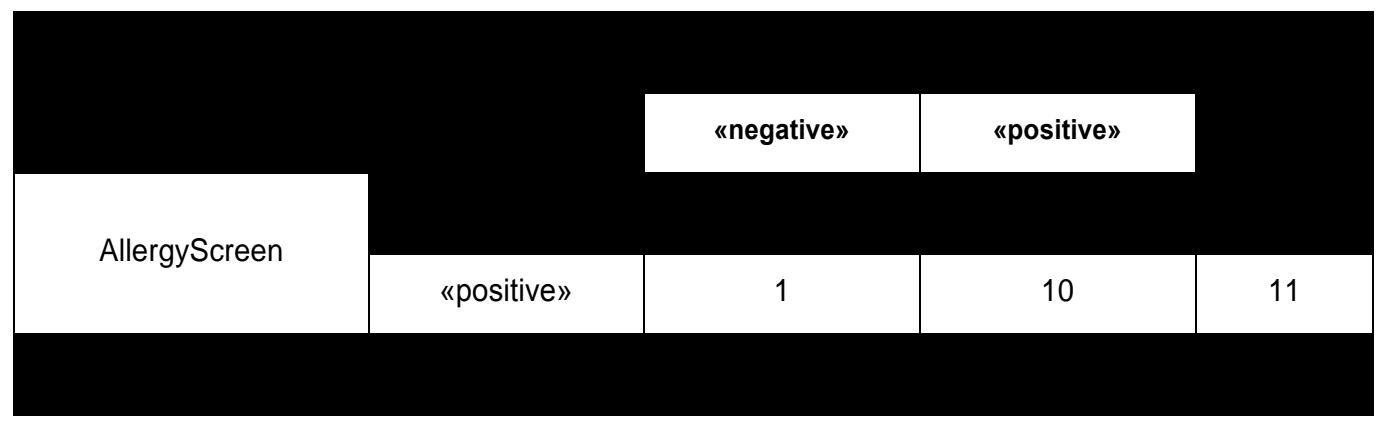

Table 2 shows the results of constructing the affinity table for the determination of specific $\lg \mathrm{E}$ to hazel.

Table 2

Summary table of the affinity of the results of determination of specific lgE to hazel allergen

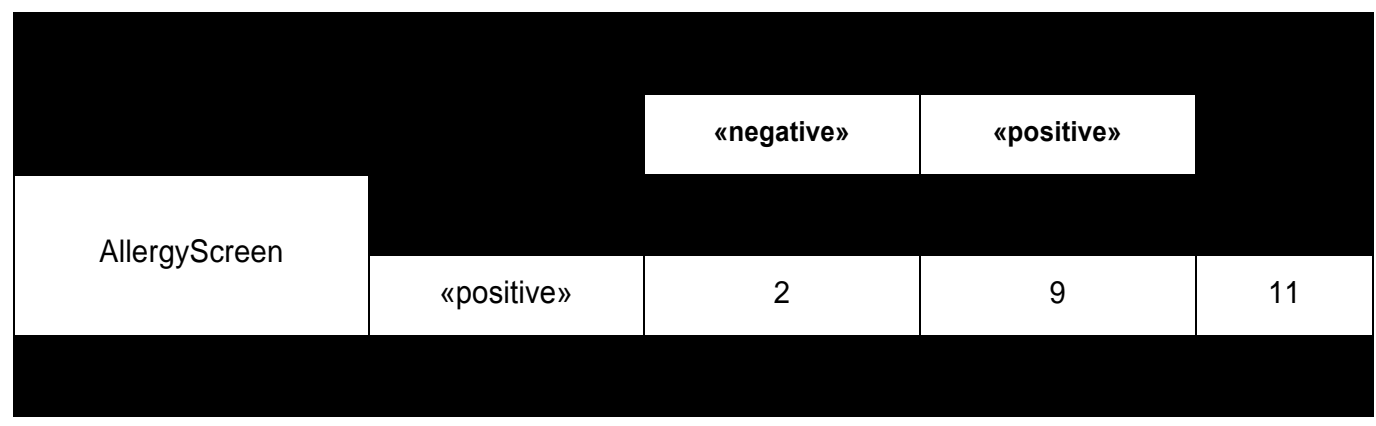

The expected frequency of the sign in one of the cells (25\%) of the summary tables below is 5 and we used the Fisher exact two-way criterion method to analyze the relationship. As a result of statistical data processing, it is determined that the absolute value of the exact two-sided Fisher criterion for the wormwood allergen corresponds to the two-sided asymptotic significance of 0.024 , which accepts the null hypothesis. At such levels of asymptotic significance, the difference between the measurement groups is the null hypothesis, and, therefore, no statistically significant difference was found between survey methods for the determination of specific $\lg E$ for allergen wormwood.

In the case of hazel allergy sensitization by two different methods, the expected symptom frequency in one of the cells $(25 \%)$ of the summary tables below 5 was also applied to analyze the relationship of the Fisher exact two-sided criterion. As a result of the statistical data processing, it is determined that the absolute value of the Fisher's exact two-sided criterion for hazel allergen corresponds to a two-sided asymptotic significance of 0.001 , which rejects the null hypothesis. At such levels of asymptotic significance, the difference between the measurement groups is null and void, and therefore a statistically significant difference was found between survey methods for the determination of specific hazelnut lgE.

For a complete analysis of the diagnostic parameters of the methods we calculated the sensitivity, specificity, accuracy, positive and negative predicitive value of the immunoblot against ImmunoCap ISAC. The results of these parameters for birch allergen are shown in table 3 . 
Diagnostic value of immunoblot versus Immunocap ISAC to determine specific $\lg \mathrm{E}$ for allergen wormwood

\begin{tabular}{|c|c|}
\hline $100.00 \%$ & $69.15 \%$ to $100.00 \%$ \\
\hline $96.67 \%$ & $82.78 \%$ to $99.92 \%$ \\
\hline $90.91 \%$ & $59.28 \%$ to $98.57 \%$ \\
\hline $100,00 \%$ & --- \\
\hline $97.50 \%$ & $86.84 \%$ to $99.94 \%$ \\
\hline
\end{tabular}

As we can see, the immunoblot has a high sensitivity and negative predictive value $(100.00 \%$ in both cases) compared to ISAC, a high specificity of $96.67 \%(95 \% \mathrm{Cl}: 82.78 ; 99.92)$, but a positive predicitive value was $90.91 \%$ (95\% Cl: 59.28; 98.57) and accuracy was $97.50 \%(95 \% \mathrm{Cl}: 86.84 ;$ 99.94).

Sensitivity is the ability of the diagnostic method to produce the correct result, which is defined as the proportion of true positive results among all tests performed. Specificity is the ability of the diagnostic method not to give in the absence of the disease false positive results, which is defined as the proportion of true negative results among healthy individuals in the group of subjects. Therefore, immunoblotting for the determination of specific IgE for allergen wormwood compared to Immunocap ISAC is highly sensitive, highly specific and highly accurate. Special attention should be paid to the positive predicitive value, which is defined as the percentage of true positive tests among all positive tests obtained as a result of the examination. In this case, it was $90.91 \%$, which indicates the possibility of a false positive result in every tenth case. The results of these parameters for hazelnut allergen are given in table. 4 .

Table 4

\section{Diagnostic value of immunoblot versus Immunocap ISAC for determination of specific IgE for hazel allergen}

\begin{tabular}{|l|l|}
\hline $75.00 \%$ & $42.81 \%$ to $94.51 \%$ \\
\hline $92.86 \%$ & $76.50 \%$ to $99.12 \%$ \\
\hline $81.82 \%$ & $53.23 \%$ to $94.68 \%$ \\
\hline $89.66 \%$ & $76.39 \%$ to $95.87 \%$ \\
\hline $87.50 \%$ & $73.20 \%$ to $95.81 \%$ \\
\hline
\end{tabular}

As we can see, immunoblot compared to ISAC for the determination of specific hazards of hazel allergen has a relatively high specificity and negative predictive value $(92.86 \%$ and $89,66 \%)$, but the sensitivity and positive predicitive value have a value of $75.00 \%(95 \% \mathrm{Cl}: 42.81 ; 94.51)$ and $81.82 \%(95 \% \mathrm{Cl}: 53.23$; $94.68)$, respectively, and the accuracy of the method is $87.50 \%(95 \% \mathrm{Cl}: 73.20 ; 95.81)$.

Therefore, the immunoblotting method for the determination of specific IgE for hazel allergen compared to Immunocap ISAC is highly specific, but medium-sensitive. Special attention should be paid to the predictability of negative and positive results, which amounted to $89.66 \%$ and $75.00 \%$, which indicates a significant possibility of false negative and false positive result. 


\title{
Discussion
}

The higher the sensitivity of the test, the more often it will detect the disease, so it is more effective. At the same time, if such a highly sensitive test proves negative, then the presence of the disease is unlikely. Therefore, they should be used to exclude diseases. Because of this, highly sensitive methods are often called identifiers, and it is recommended to use them in the early stages of the diagnostic process, when you need to narrow down the range of suspected diseases. On the other hand, the higher the specificity of the method, the more reliable it is to confirm the disease, and therefore, it is more effective. Highly specific methods are called discriminators in diagnosis. Such studies are effective in the second stage of diagnosis, when the range of suspected diseases is narrowed and it is necessary to prove with great certainty the presence of the disease.

The results of the analysis showed high sensitivity, specificity and accuracy of immunoblotting for the determination of IgE specific for allergen wormwood compared to Immunocap ISAC, as well as high specificity, moderate sensitivity and accuracy for determination of specific $\lg E$ for the allergen of hazel.

In our opinion, there may be a number of factors that may cause such differences. The main point is that the increase in the sensitivity of the test is inevitably accompanied by the loss of its specificity, and vice versa, the increase in specificity is associated with a decrease in its sensitivity. Diagnosis techniques with high sensitivity rarely «miss» patients who have the disease, and techniques with high specificity do not qualify as healthy patients. On the other hand, the reduced sensitivity of the method may be directly related to the immunoblotting technique itself, since photometric analysis depends in practice on many factors - the quality of the scan, the correct preparation procedures, the presence or absence of calibration, and the like.

The negative predicitive value is defined as the frequency of its coincidence with the absence of the disease. This criterion thus shows how likely the patient is to be healthy if the results of the study are negative. In our case, the negative predictive value for the immunoblot method is generally related to the sensitivity of the method.

\section{Summary}

As we can see, for the determination of specific $\lg E$ to wormwood allergen the immunoblot has a high sensitivity and negative predictive value $(100.00 \%$ in both cases) compared to ISAC, a high specificity of 96.67\% (95\% Cl: 82.78; 99.92), but a positive predicitive value was $90.91 \%(95 \% \mathrm{Cl}: 59.28 ; 98.57)$ and accuracy was $97.50 \%$ (95\% Cl: 86.84 ; 99.94).

Immunoblot compared to ISAC for the determination of specific IgE to hazel allergen has a relatively high specificity and negative predictive value $(92.86 \%$ and $89,66 \%)$, but the sensitivity and positive predicitive value were $75.00 \%$ (95\% Cl: 42.81 ; 94.51) and $81.82 \%$ (95\% Cl: 53.23; 94.68), respectively, and the accuracy of the method was $87.50 \%(95 \% \mathrm{Cl}: 73.20 ; 95.81)$.

\section{PEЗЮME}

\section{ВИЗНАЧЕННЯ СЕНСИБІЛІЗАЦІЇ ДО ПИЛКОВИХ АЛЕРГЕНІВ ПОЛИНУ ТА ЛІЩИНИ У ХВОРИХ НА РЕСПІРАТОРНІ АЛЕРГІЧНІ ЗАХВОРЮВАННЯ ЗА ДОПОМОГОЮ ІМУНОБЛОТУ ТА МУЛЬТИПЛЕКСНОГО КОМПОНЕНТНОГО ТЕСТУВАННЯ}

\author{
Богомолов A.є. ${ }^{1}$, Зайков C.B. ${ }^{2}$ \\ ${ }^{1}$ Вінницький національний медичний університет \\ ім. М.І. Пирогова \\ ${ }^{2}$ Національна медична академія післядипломної \\ освіти ім. П.Л. Шупика
}

\footnotetext{
Метою нашого дослідження було оцінити діагностичні параметри методів імуноблоту та Immunocap ISAC для визначення сенсибілізації до алергенів полину та ліщини у пацієнтів з респіраторними алергічними захворюваннями - алергічним ринітом та бронхіальною астмою.

Матеріали та методи. У процесі цього дослідження двома різними методами специфічної алергологічної діагностики (in vitro) було обстежено 40 пацієнтів, хворих на бронхіальну астму та / або алергічний риніт. Дослідження було відкритим, порівняльним. Кількісне визначення специфічних $\lg$ в с сироватці крові проводили за допомогою методу імуноблоту «RIDA® AllergyScreen» (R-Biopharm AG, Німеччина) на базі приватної лабораторії ТОВ «Алерго-імунологічний центр КПП». Обстеження методом Immunocap ISAC було виконане у «Клініці
} 
алергології та імунології «Форпост»».

Результати та обговорення. Серед пацієнтів алергічна сенсибілізація до полину становила 27,5\% (11 осіб) за наявності специфічного IgE методом Rida AllergyScreen, 25,0\% (10 осіб) за наявності специфічного IgE за допомогою ImmunoCAP ISAC; сенсибілізація до алергену ліщини становила 27,5\% (11 осіб) за наявності специфічного IgE на Rida AllergyScreen, 30,0\% (12 осіб) за наявності специфічного IgE від ImmunoCAP ISAC.

Для визначення специфічного $\mathrm{IgE}$ до алергену на полин імуноблот має високу чутливість та прогностичність негативного результату (100.00\% в обох випадках) порівняно з ISAC, високу специфічність 96,67\% (95\% ДІ: 82,78; 99,92) , але прогностичність позитивного результату становила 90,91\% (95\% ДІ: 59,28; 98,57), а точність - 97,50\% (95\% ДІ: 86,84; 99,94).

Висновки. Імуноблот порівняно з ISAC для визначення специфічного IgE до алергену ліщини має відносно високу специфічність та прогностичність негативного результату (92,86\% та 89,66\%), але значення чутливості та прогностичності позитивного результату становили 75,00\% (95\% ДІ: 42,81; 94,51) і 81,82\% (95\% ДІ: 53,23; 94,68), відповідно, а точність методу становила 87,50\% (95\% ДІ: 73,20; 95,81).

Ключові слова: алергія, імуноблотинг, $\lg \mathrm{E}$, молекулярна алергологія.

\title{
PEЗЮME \\ ОПРЕДЕЛЕНИЕ СЕНСИБИЛИЗАЦИИ К ПЫЛЬЦЕВЫМ АЛЛЕРГЕНАМ ПОЛЫНИ И ОРЕШНИКА У БОЛЬНЫХ РЕСПИРАТОРНЫМИ АЛЛЕРГИЧЕСКИМИ ЗАБОЛЕВАНИЯМИ С ПОМОЩЬЮ ИММУНОБЛОТА И МУЛЬТИПЛЕКСНОГО КОМПОНЕНТНОГО ТЕСТИРОВАНИЯ
}

\author{
Богомолов A.E. ${ }^{1}$, Зайков C.B. ${ }^{2}$ \\ ${ }^{1}$ Винницкий национальный медицинский университет \\ им. М.И. Пирогова
}

${ }^{2}$ Национальная медицинская академия последипломного образования им. П.Л. Шупика

Целью нашего исследования было оценить диагностические параметры методов иммуноблота и Immunocap ISAC для определения сенсибилизации к аллергенам полыни и орешника у пациентов с респираторными аллергическими заболеваниями - аллергическим ринитом и бронхиальной астмой.

Материалы и методы. В процессе этого исследования двумя различными методами специфической аллергологической диагностики (in vitro) было обследовано 40 пациентов с бронхиальной астмой и / или аллергическим ринитом. Исследование было открытым, сравнительным. Количественное определение специфических IgE в сыворотке крови проводили с помощью метода иммуноблота «RIDA® AllergyScreen» (R-Biopharm AG, Германия) на базе частной лаборатории ООО «Аллерго-иммунологический центр КПП». Обследование методом Immunocap ISAC было выполнено в «Клинике аллергологии и иммунологии «Форпост»».

Результаты и обсуждение. Среди пациентов аллергическая сенсибилизация к полыни составила 27,5\% (11 человек) при наличии специфического IgE методом Rida AllergyScreen, 25,0\% (10 человек) при наличии специфического IgE с помощью ImmunoCAP ISAC; сенсибилизация к аллергену орешника составила 27,5\% (11 человек) при наличии специфического IgE на Rida AllergyScreen, 30,0\% (12 человек) при наличии специфического IgE от ImmunoCAP ISAC.

Для определения специфического $\lg$ к к аллергену полыни иммуноблот имеет высокую чувствительность и прогнозируемость отрицательного результата (100.00\% в обоих случаях) по сравнению с ISAC, высокую специфичность 96,67\% (95\% ДИ: 82,78; 99,92), но прогнозируемость положительного результата составила 90,91\% (95\% ДИ: 59,28; 98,57), а точность - 97,50\% (95\% ДИ: 86,84; 99,94).

Выводы. Иммуноблот, по сравнению с ISAC для определения специфического IgE к аллергену орешника, имеет относительно высокую специфичность и прогнозируемость отрицательного результата (92,86\% и 89,66\%), но чувствительность и прогнозируемость положительного результата составляли 75,00\% (95\% ДИ: $42,81 ; 94,51)$ и $81,82 \%$ (95\% ДИ: 53,23; 94,68), соответственно, а точность метода составила 87,50\% (95\% ДИ: $73,20 ; 95,81)$.

Ключевые слова: аллергия, имуноблотинг, $\lg \mathrm{E}$, молекулярная аллергология.

\section{SUMMARY}

\section{DEFINITION OF SENSITIZATION TO POLLEN ALLERGENS WORMWOOD AND HAZEL IN PATIENTS WITH RESPIRATORY ALLERGIC DISEASES BY IMMUNOBLOT AND MULTIPLEX COMPONENT TEST}

\author{
Bogomolov A.E. ${ }^{1}$, Zaykov S.V. ${ }^{2}$ \\ ${ }^{1}$ Vinnitsia National Medical University named after M.I. Pirogov \\ ${ }^{2}$ National Medical Academy of Postgraduate Education named after P.L. Shupika
}

The aim of our study was to evaluate the diagnostic parameters of immunoblot and Immunocap ISAC methods to determine allergic sensitization to wormwood and hazel in patients with respiratory allergic diseases - allergic rhinitis and bronchial asthma. 
Materials and methods. In this study, 40 patients with bronchial asthma and / or allergic rhinitis were examined with two different methods of specific allergic diagnosis (in vitro). The study was open-ended, comparative. Quantitative determination of specific IgE in the serum was performed using the RIDA $®$ AllergyScreen immunoblot method (R-Biopharm AG, Germany) on the basis of the private laboratory of LLC "Allergy-Immunological Center KPP". Immunocap ISAC testing was performed at "Forpost Allergy and Immunology Clinic".

Results and Discussion. Among patients, allergic sensitization to wormwood was $27.5 \%$ (11 people) in the presence of specific IgE by the Rida AllergyScreen method, 25.0\% (10 people) in the presence of specific IgE using ImmunoCAP ISAC; sensitization to hazel allergen was $27.5 \%$ (11 people) in the presence of specific IgE on Rida AIlergyScreen, $30.0 \%$ (12 people) in the presence of specific IgE from ImmunoCAP ISAC.

For the determination of specific IgE to wormwood allergen the immunoblot has a high sensitivity and negative predictive value $(100.00 \%$ in both cases) compared to ISAC, a high specificity of $96.67 \%(95 \% \mathrm{Cl}: 82.78 ; 99.92)$, but a positive predicitive value was $90.91 \%(95 \% \mathrm{Cl}: 59.28$; 98.57$)$ and accuracy was $97.50 \%(95 \% \mathrm{Cl}: 86.84 ; 99.94)$.

Conclusions. Immunoblot compared to ISAC for the determination of specific IgE to hazel allergen has a relatively high specificity and negative predictive value $(92.86 \%$ and $89,66 \%)$, but the sensitivity and positive predicitive value were $75.00 \%(95 \% \mathrm{Cl}: 42.81 ; 94.51)$ and $81.82 \%(95 \% \mathrm{Cl}: 53.23 ; 94.68)$, respectively, and the accuracy of the method was $87.50 \%(95 \% \mathrm{Cl}: 73.20 ; 95.81)$.

Keywords: allergy, immunoblotting, IgE, molecular allergy.

\section{ЛITEPATУPA}

Frati F, Incorvaia C, Cavaliere C, et al. The skin prick test. J Biol Regul Homeost Agents. 2018;32(1 Suppl. 1):19-24.

Nevis IF, Binkley $K$, Kabali $C$. Diagnostic accuracy of skin-prick testing for allergic rhinitis: a systematic review and meta-analysis. Allergy Asthma Clin Immunol. 2016;12:20. Published 2016 Apr 27. doi:10.1186/s13223-016-0126-0

Sadok Y. Diagnostic au laboratoire de l'hypersensibilite immediate [Diagnosis of type I hypersensitivity by laboratory test]. Tunis Med. 2005;83(8):441-444.

Westwood M, Ramaekers $B$, Lang $S$, et al. ImmunoCAP® ISAC and Microtest for multiplex allergen testing in people with difficult to manage allergic disease: a systematic review and cost analysis. Health Technol Assess. 2016;20(67):1-178. doi:10.3310/hta20670

Van Hage M, Hamsten C, Valenta R. Immu-noCAP assays: Pros and cons in allergology. J Allergy Clin Immunol. 2017; 140(4):974-977. doi:10.1016/j.jaci.2017.05.008

\section{АВТОРСЬКА ДОВІДКА}

\section{Богомолов Артемій Євгенович}

Кандидат медичних наук, доцент кафедри фтизіатрії з курсом клінічної імунології Вінницького національного медичного університету ім. М.І. Пирогова

Адреса: 21018, Україна, Вінниця,

вул. Пирогова, 56

Тел.моб.: +380970663555

E-mail: art.bogomolov@gmail.com

orcid.org/0000-0002-5336-4858

\section{Богомолов Артемий Евгеньевич}

Кандидат медицинских наук, доцент кафедры фтизиатрии с курсом клинической иммунологии Винницкого национального медицинского университета им. М.И. Пирогова

Адрес: 21018, Украина, Винница,

ул. Пирогова, 56

Тел.моб.: +380970663555

E-mail: art.bogomolov@gmail.com

orcid.org/0000-0002-5336-4858

\section{Bogomolov Artemii}

Candidate of Medical Sciences, associate professor of phthisiology, clinical immunology and allergy department, National Pirogov memorial medical university

Address: 21000, Pirogova, 56, Vinnytsya, Ukraine,

Tel.mob.: + 380970663555

E-mail: art.bogomolov@gmail.com 
orcid.org/0000-0002-5336-4858

\section{Зайков Сергій Вікторович}

Доктор медичних наук, професор кафедри фттиіатрії та пульмонології НМАПО ім. П.Л. Шупика, Київ, Україна Адреса: 04112 вулиця Дорогожицька, 9, Київ, Україна

Тел.моб.: +38050 3832333

E-mail: zaikov1960@gmail.com

orcid.org/0000-00029276-0490

\section{Зайков Сергей Викторович}

Доктор медицинских наук, профессор кафедры фртизиатрии и пульмонологии НМАПО им. П.Л. Шупика, Киев, Украина

Адрес: 04112 улица Дорогожицкая, 9, Киев, Украина

Тел.моб.: +38050 3832333

E-mail: zaikov1960@gmail.com

orcid.org/0000-00029276-0490

\section{Zaikov Serhii}

Doctor of Medical Sciences, professor Shupyk National Medical Academy of Postgraduate Education, Kyiv, Ukraine Address: 04112 Dorogozhitska Street, 9, Kyiv, Ukraine

Tel.mob.: +380503832333

E-mail: zaikov1960@gmail.com

orcid.org/0000-00029276-0490 